To cite this article: İneç, Z.F. (2021). A Dynamic Map Design for Global Awareness in Social Studies Teaching. Romanian Review of Geographical Education, 10(2), 5-21. DOI: 10.24193/RRGE220211

ROMANI AN REVIEW OF GEOGRAPHICAL EDUCATION

Volume X, Number 2, August 2021

pp. 5-21

DOI: $10.24193 /$ RRGE220211

\title{
A DYNAMIC MAP DESIGN FOR GLOBAL AWARENESS IN SOCIAL STUDIES TEACHING*
}

\author{
ZEKERİYA FATİH İNEÇ \\ Erzincan Binali Yildirim University, Faculty of Education, Erzincan, Turkey, \\ e-mail: fatihinec@erzincan.edu.tr
}

(Received: March 2021; in revised form: April 2021)

\begin{abstract}
In this study, the stages of creating a dynamic map in Microsoft Excel with the rapid prototyping instructional design model developed by Tripp and Bichelmeyer are explained to support and improve students' global awareness in social studies lessons in Turkey. The dynamic map was created in four general stages in the study, in which the waterfall design model was adopted. First, the needs and content analysis of the study were conducted for this aim. In the second stage, an algorithm was created in line with the determinations of the first stage, and, within this framework, the prototype of the dynamic map was designed in Microsoft Excel. In the third stage, the working status of the dynamic map was checked, the design process was completed, and the distortions on the coordinate system were eliminated. In the last stage, the dynamic map was evaluated by three experts, and the final prototype was created based on their feedback. The study was conducted using action research, the reflections of the acquisitions in the dynamic map are evaluated descriptively, and the opinions about the dynamic map are evaluated with content analysis. According to the obtained results, the dynamic map can reflect the acquisitions, concretize the content, and increase students' map literacy levels, but it also requires teacher support. In addition, the map also supports the competencies in teaching programs with mathematics and learning skills. Suggestions based on these results are also provided for educators and researchers.
\end{abstract}

Keywords: rapid prototyping instructional design model, dynamic maps, digital instructional materials, global connections.

\footnotetext{
* This study was presented as a summary of "A dynamic map design for global awareness in social studies teaching" at the 3rd International Turkish World Congress of Educational and Social Sciences held in Ankara/Turkey on 10-12 Novem ber 2020.
} 


\section{NTRODUCTI ON}

Focusing on the interactions of people with the society and their environments, social studies courses aim to produce individuals who can perceive universal values by assimilating local and national values, raising effective citizens (Kabapınar, 2014, p. 3). In this context, social studies courses have special tasks ranging from local to universal values. Global awareness is considered a special behavioural skill that individuals should acquire due to globalization. However, this concept, which is perceived as a level of consciousness, needs to be included in education and training programs (Burnouf, 2004). This is because the major problems arising in the globalization process make people directly or indirectly dependent on each other, thus transforming the created global awareness into sensitivity (Gibson, Rimmington \& Landwehr-Brown, 2008). This awareness (Karasar, 2019, pp. 8-9), which is described as new perceptions, and is constantly becoming more robust, is one of the sub-dimensions of the term global literacy (Çakmak \& Bulut, 2019).

The relationship between the concept of global awareness and education is dealt with in five dimensions. For learners to have global awareness, they must have a conscious perspective, a certain level of knowledge about the world, perceptions towards cultures, an understanding of global dynamics, and sensitivity to understand people's preferences (Hanvey, 1975, pp. 1-28, 1982). However, the literature emphasizes that the concept of global awareness is an important component of globalization. Therefore, it is necessary to reconsider and make sense of new skills, values, thoughts, sensitivities, and awareness in the neighbourhood of a country where globalization is focused. It is possible to minimize globalization's negative effects (Bayar, 2008; Karip, 2005), which are considered inevitable, by creating new awareness in this way. Therefore, the concept of global awareness is reinterpreted from a different perspective, in line with national interests. It is characterized as the perception of the effects of globalization and being conscious of them. To put this thought into action, in this study are explained the design and development processes of a simple dynamic map, to support and improve students' global awareness in social studies courses.

\section{Purpose of the research}

This study explains the process of creating a dynamic map in Microsoft Excel to support and improve students' global awareness in social studies lessons. For this purpose, a rapid prototyping instructional design model was used. Social studies education experts evaluated the dynamic map using a qualitative approach. In this framework, the reflection levels of each acquisition on the dynamic map and experts' opinions about the dynamic map were determined. 


\section{Relevance of this research}

In this study, global awareness is defined, and the stages of creating a dynamic map are explained accordingly. Thus, social studies teachers provided information support to create simple dynamic maps and help students perceive the concept of global awareness. The study is important in terms of aiding to increase social studies teachers' digital literacy skills. The relevant subjects are generally comprehended through maps (Bednarz, Acheson \& Bednarz, 2006; Darakçı, 2014). Maps are the most used materials in social studies and geography lessons and the use technologybased maps in the social science lessons increases the students' motivation to study the lesson (Çelikkaya, 2013; Meydan \& Öner, 2014; Taşlı, Çelik \& Taşlı, 2006; Ulusoy \& Gülüm, 2009; Yazıcl, 2006). Occasionally, in textbooks, there are figures instead of maps (Oruç \& Liman, 2012), but the use of maps in textbooks is constantly increasing (Bekdemir \& Polat, 2016), and developing mapping skills in social sciences are limited in the literature (Dulamă, 2014; Dulamă \& Ilovan, 2016; Dulamă, Ilovan \& Niţoaia, 2016). However, it is understood that the socio-economic level of the map users affects the use of maps (Duman, 2011). In particular, the literature shows that social studies teachers' mapping skills are higher than those of history and geography teachers working in the state schools in Turkey (Sönmez \& Aksoy, 2012).

There is limited research focus on the development of a dynamic map in education and this study is original and important in terms of creating a dynamic map that reflects the concept of global awareness, where the meanings of complex consciousness levels are loaded, and a curriculum in which understanding of the acquisitions in the program is attempted.

\section{METHOD}

\section{Research model}

In the study, action research was conducted to identify the problems that may arise during the dynamic map application phase and produce solutions. Action research is a process-oriented design focusing on problems and processes in teaching (Yıldırım \& Şimşek, p. 84). In this framework, the opinions of social studies teaching experts participating in the study on the acquisitions in the social studies program in Turkey reflected on the map and the dynamic map were determined through standardized open-ended interviews.

\section{Study group}

Since the study aimed to introduce a new application and innovation, experts in this field were included in the evaluation process. In this context, the study was conducted with three social studies teaching experts chosen via typical case sampling. The participants work as teachers in different public schools in Turkey (Table 1). 
Table 1. Participants

\begin{tabular}{lll}
\hline Nickname & Gender & Level of Education \\
Teacher_1 & Female & Master's degree \\
Teacher_2 & Female & Master's degree \\
Teacher_3 & Male & Doctoral degree \\
\hline
\end{tabular}

\section{Data collection tools}

In this study, a semi-structured interview form, including two questions, was used to obtain social studies teaching experts' general views on the acquisitions reflected by the dynamic map itself. This form was developed with the relevant literature (MoNE, 2018) and expert opinions. The online form was shared with the study group via e-mail.

\section{Data analysis}

The perspectives of social studies teaching experts about the dynamic map were examined descriptively, and their views on the dynamic map were analysed with content analysis. While descriptive analysis was adopted to analyse the reflected acquisitions in this study as themes, content analysis was used to identify themes in the expert opinions (Patton, 2018, p. 453). To determine the reliability of the analyses, the Miles and Huberman (1994) reliability formula was used to determine the significance and compatibility of the datasets. The results show that descriptive analysis is $97 \%$ reliable and content analysis is $91 \%$ reliable. If the intercoder agreementvalue is above $90 \%$, the analysis results are reliable (Miles \& Huberman, 1994, p. 64).

\section{Research process}

The study was conducted in 2020. First, the instructional design process for the dynamic map was started, and the dynamic map was created. Depending on the instructional design, the social studies education experts ended the process with testing and evaluation.

\section{Material}

The research was conducted with the rapid prototyping instructional design model, developed by Tripp and Bichelmeyer (1990) to realize the instructional design of short courses instead of an entire curriculum. Therefore, it is understood that the model is used in the development of small applications. The first instructional design stage begins with needs and content analysis. It continues by determining the expected outcomes of the social studies curriculum. In the second stage, the design and development process of the prototype for instructional design is explained. In the third stage, the target audience conducts the pilot use of the product created in the previous stage. In the last stage, the implementation and 
control of the instructional design process are completed (Ocak, 2011, pp. 82-84). The classical design (waterfall) model has been adopted in the study.

The stages of developing a dynamic map material according to the rapid prototyping model are outlined below.

\section{Needs and content analysis}

At this stage, first, a needs analysis was conducted, and the problems social studies teachers experienced when creating a digital map were discussed. Based on the determinations, the use of parameters of computer programming or application programming interfaces was first planned. However, in terms of accessibility and simplicity, the Microsoft Excel program was preferred to facilitate the work of social studies teachers as they did not have to engage in coding.

Content analysis was conducted in line with the results of the needs analysis. In this context, it was decided that the dynamic map would include global problems and reflect this in social studies lessons. In contrast, the content is thought to reflect the global connections learning field and the acquisitions in the curriculum listed below. In this framework, the learning area was examined, and the content was reflected in the way that the concept of global awareness is handled. In addition, it has been determined that the acquisitions can be transferred to the dynamic map to cover all learning areas. These acquisitions are the following (MoNE, 2018):

- Sixth Grade - Outcome.6.7.3. The student analyses Turkey's international roles based on its political, military, economic and cultural characteristics.

- Seventh Grade - Outcome.7.7.1. The student gives examples of international organizations of which Turkey is a member.

- Seventh Grade - Outcome.7.7.2. The student recognizes the economic regions and organizations with which Turkey is associated.

- Seventh Grade - Outcome.7.7.4. The student develops ideas for solving global problems with classmates.

The data obtained from the content analysis are reflected in the dynamic map to include global problems; the concepts of natural disasters, famine, terror, war and migration are sample sub-data (MoNE, 2018). In addition, the world is divided into five regions: North America, South America, Europe, Africa, and Asia.

\section{Prototype development (design)}

An algorithm was created to design the prototype to be developed in the study with the data obtained from the needs and analysis stages. Thus, the development process of the prototype in Microsoft Excel was conducted through this algorithm. The graphic interface design of the map was then made (Figure 1). 


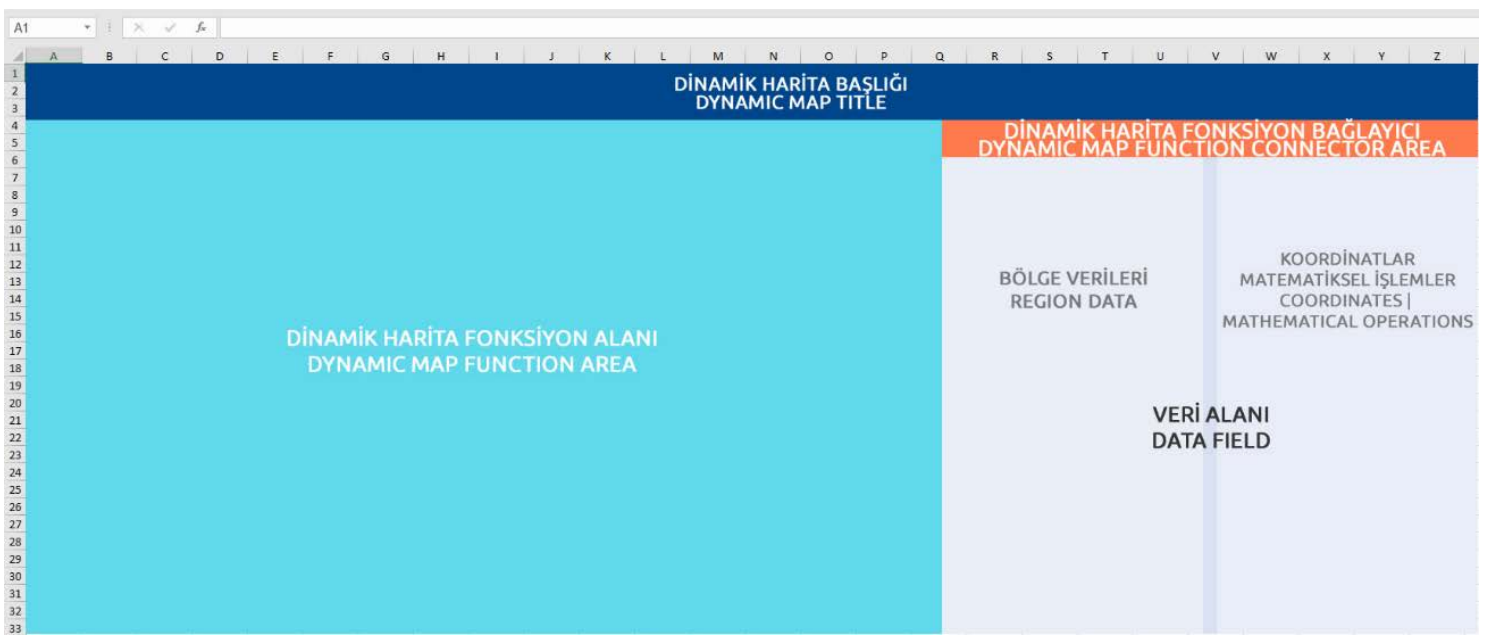

Fig. 1. Dynamic map graphic interface design

To create a dynamic map, some cells were combined, and the text and data to be added were displayed. The use of large fonts in the fields expressed as heading and function binding required the merging of columns and cells. Therefore, the map title text field, the dynamic map function connector field, which enables the map type selection, is left blank. After the visualization process, only the parameters were written in the area defined on the global problems and region data graphical interface. No formula was written (Figure 2).

\begin{tabular}{|c|c|c|c|c|}
\hline \multicolumn{2}{|r|}{ Events Olay } & Bölge Region & \multicolumn{2}{|c|}{ Events Size Büyüklük } \\
\hline \multirow{5}{*}{ 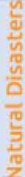 } & Doğal Afet & Kuzey Amerika & Nerth Amerigr & 90 \\
\hline & Doğal Afet & Güney Amerika & South America & 30 \\
\hline & Doğal Afet & Avrupa & Europe & 40 \\
\hline & Doğal Afet & Afrika & $\begin{array}{l}\text { Arrica } \\
\text { Asia }\end{array}$ & 10 \\
\hline & Doğal Afet & Asya & & 40 \\
\hline \multirow{5}{*}{ 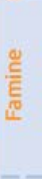 } & Açlık & Kuzey Amerika & North America & 5 \\
\hline & Açlık & Güney Amerika & South America & 30 \\
\hline & Açlık & Avrupa & Europe & 10 \\
\hline & Açlık & Afrika & $\begin{array}{l}\text { Africa } \\
\text { Asia }\end{array}$ & 90 \\
\hline & Açlık & Asya & & 60 \\
\hline \multirow{5}{*}{ 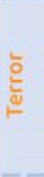 } & Terör & Kuzey Amerika & North America & 10 \\
\hline & Terör & Güney Amerika & South America & 30 \\
\hline & Terör & Avrupa & Europe & 20 \\
\hline & Terör & Afrika & $\begin{array}{l}\text { Africa } \\
\text { Asia }\end{array}$ & 50 \\
\hline & Terör & Asya & & 80 \\
\hline \multirow{5}{*}{$\begin{array}{l}\frac{10}{3} \\
\end{array}$} & Savaş & Kuzey Amerika & North America & 0 \\
\hline & Savaş & Güney Amerika & South America & 20 \\
\hline & Savaş & Avrupa & Europe & 10 \\
\hline & Savaş & Afrika & $\begin{array}{l}\text { Africa } \\
\text { Asja }\end{array}$ & 50 \\
\hline & Savaş & Asya & & 90 \\
\hline \multirow{5}{*}{$\begin{array}{l}\frac{5}{0} \\
\frac{1}{0} \\
\frac{5}{\Sigma} \\
\Sigma\end{array}$} & Göç & Kuzey Amerika & & 10 \\
\hline & Göç & Güney Amerika & South America & 40 \\
\hline & Göç & Avrupa & Europe & 10 \\
\hline & Göç & Afrika & $\begin{array}{l}\text { Africa } \\
\text { Asia }\end{array}$ & 70 \\
\hline & Göç & Asya & & 80 \\
\hline
\end{tabular}

Fig. 2. Global issues and regions 
Bubble charts were used to create the dynamic map and determine the coordinates. The selection of this chart type involved showing the relationship between value sets in three dimensions. The bubble chart was placed in the dynamic map function area in the interface design. The bubble chart with a white background was selected and the format graphics area menu switched to the menu on the right. The picture or texture fill was selected from the options here, and, after selecting the image source, the add button was clicked. On the screen that opened, the desired world image (MTBlack, 2016) was selected from the file or online pictures, and th us the background picture of the bubble chart was determined. In fact, the goal here was to create the $x$ and $y$ coordinate plane and choose a world graph as the ground image for it. Therefore, selecting a bubble chart resulted in Microsoft Excel, actually creating an $x, y$ coordinate system. However, these coordinate values were defined manually.

For this purpose, the five main regions specified in the previous stage were written as text in the "coordinates | mathematical operations" field in the intermediate chart percentage. The parametric values in the $x$ and $y$ planes were then defined as numbers, and no formulas were written. To transform the values assigned by the user into the coordinate parameters of the bubble chart, it was necessary to first right click on the bubble chart and then select data from the drop-down menu. A new indicator input was created from this screen and provided to define the $x, y$ values in the coordinate system with manually entered $x, y$ values (Figure 3 ).

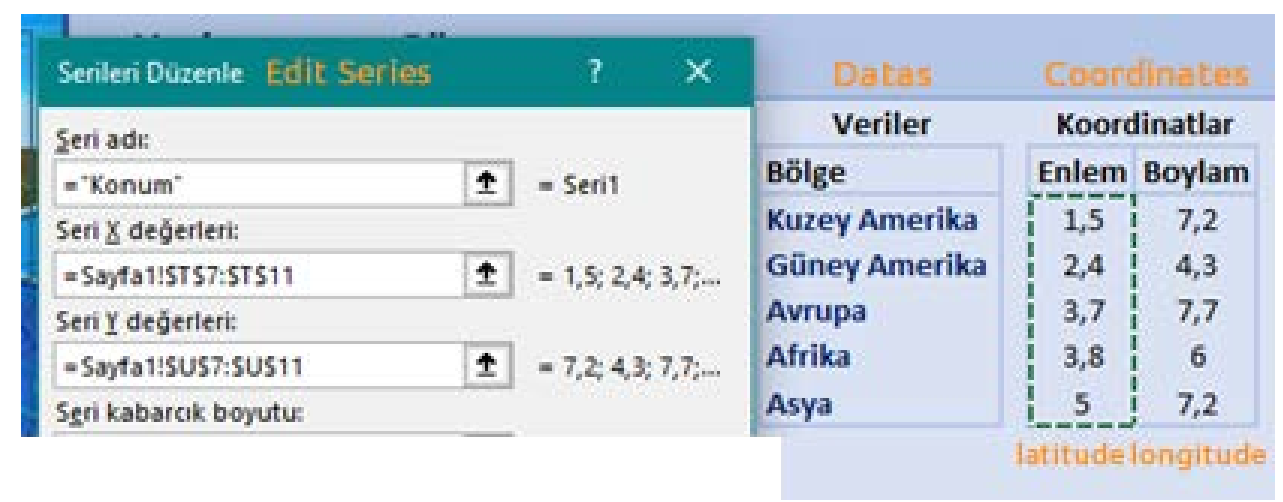

Fig. 3. Assigning $x, y$ values to a bubble chart

For the creation of map types, Microsoft Excel's data validation feature was used. After selecting a cell in the dynamic map function connector area, where the map type was displayed, "the data $>$ data validation $>$ data validation" selection was made. The window that appeared was selected as the allowed list, and the source "subtitles of global problems" was chosen (Figure 4). 


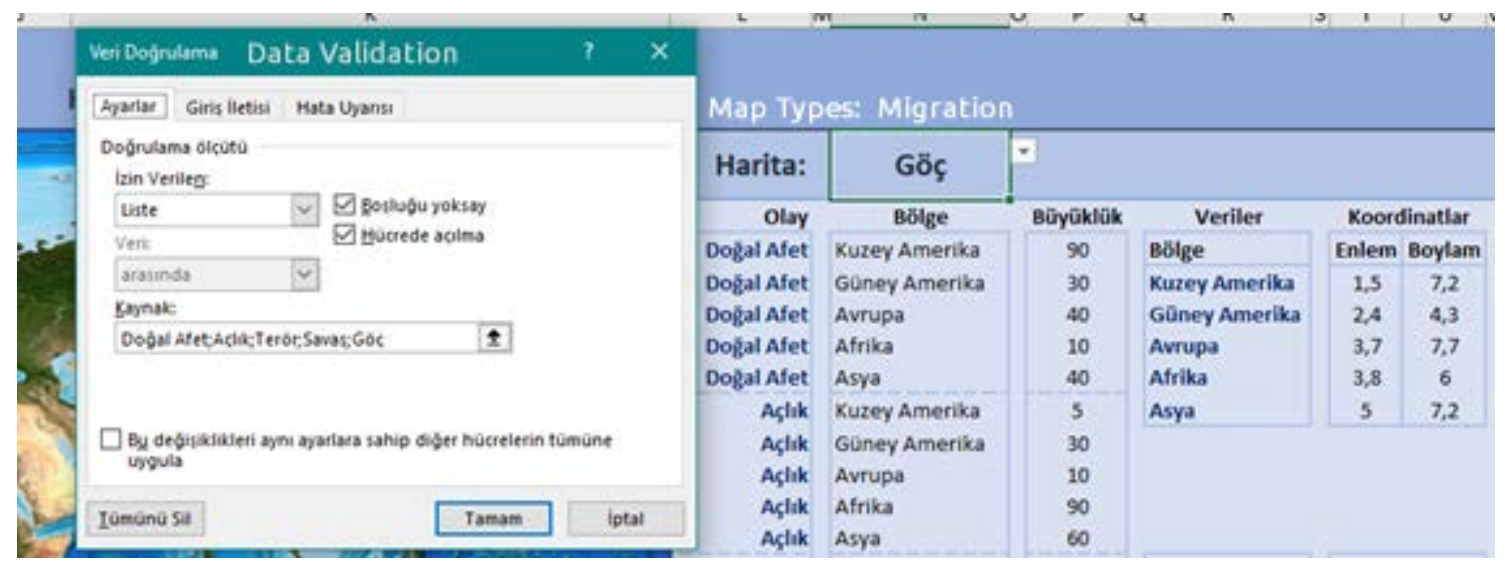

Fig. 4. Data validation

After the map type was selected, the multitool formula for classifying the data according to the regions was written. This formula enables the determination of map types and makes the map dynamic. The multiverse formula is a function of algebra and trigonometry, and it collects arguments with varying criteria (Microsoft Support, n.d.). The multivariate formula consists of syntax of multiverse (range_total; criteria_range1; criteria1; [criteria_range2; criteria2]; ...).

- range total: the addresses of the cells showing the size data of the five regions (area within the region data, blue selection),

- criteria_range1: the cell addresses of sub-data themes of global issues (area within region data, red selection),

- criterion 1: the cell address of the list of map types created by data validation (dynamic map function connector area, purple selection),

- criteria_range2: the addresses of the cells belonging to the five zone rows (area within the zone data, green selection),

- criterion2: the addresses of cells belonging to the five regions (coordinates | mathematical operations area, fuchsia selection).

Values are defined for the above parameters. This formula should be written for the first cell in the "coordinates | mathematical operations" field and then transferred to others (Figure 5). 
A DYNAMIC MAP DESIGN FOR GLOBAL AWARENESS ...

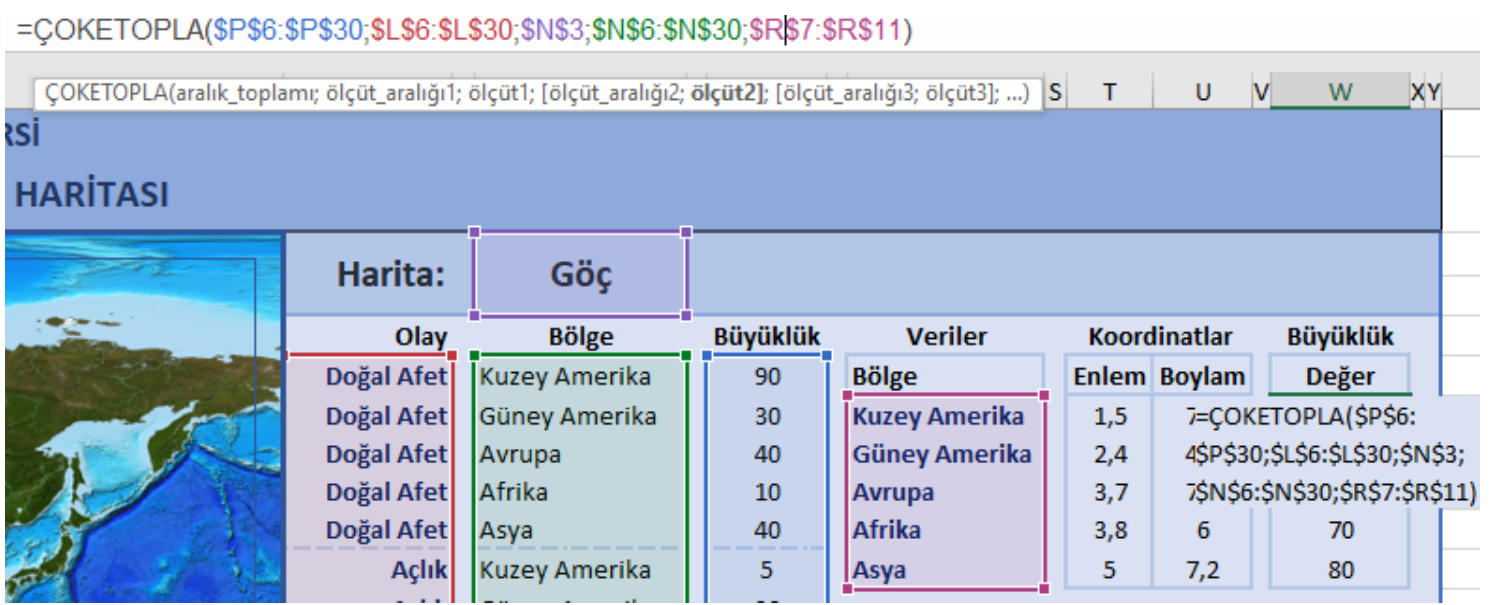

Fig. 5. Classification of data for regions

For the dynamic map to determine the peak value by associating global events with regions, it is necessary to write a logical test formula. The aim is to express the highest value in a range in a given cell. This formula is written and explained as follows:

- =if(logical_test,if_value_true,if_value_false)

- =if(region_expression_size_value_cell=MAK(region_expression_size_ first_value_cell:region_expression_size_second_value_cell);region_expres sion_size_value_cell;"'")

after if;

- logical_test: the cell where the multitool operation is performed according to the region to be associated,

- if_value_true: first logical test cell address,

- if_value_false: the last logical test cell address.

To insert the formula, the place next to the value column for the five regions in the "coordinates | mathematical operations field" was evaluated. The peak values became dynamic when the map type was selected after the logical test formula was written (Figure 6). 
ZEKERIYYA FATİH İNEÇ

\begin{tabular}{|c|c|c|c|c|c|c|c|}
\hline Harita: & Açlık & & & & & & \\
\hline Olay & Bölge & Büyüklük & Veriler & Koord & linatlar & Büyüklük & \\
\hline Doğal Afet & Kuzey Amerika & 90 & Bölge & Enlem & Boylam & Değer & Tepe Değer \\
\hline Doğal Afet & Güney Amerika & 30 & Kuzey Amerika & 1,5 & 7,2 & 5 & \\
\hline Doğal Afet & Avrupa & 40 & Güney Amerika & 2,4 & 4,3 & 30 & \\
\hline Doğal Afet & Afrika & 10 & Avrupa & 3,7 & 7,7 & 10 & \\
\hline Doğal Afet & Asya & 40 & Afrika & 3,8 & 6 & 90 & 90 \\
\hline Açlık & Kuzey Amerika & 5 & Asya & 5 & 7,2 & 60 & \\
\hline Açlık & Güney Amerika & 30 & & & & & \\
\hline Açlık & Avrupa & 10 & & & & & \\
\hline Açlık & Afrika & 90 & & & & & \\
\hline
\end{tabular}

Fig. 6. Finding the peak value with logical classification

After the formulas and parameter values were defined, the dynamic map functioned correctly. In this context, it was possible to make some visual improvements. For example, the coordinate values around the map and the chart naming tables could be deleted. Again, in the study, cells were coloured to ensure the distinctiveness of the data, and areas were separated from each other by lines. In addition, the colours of the threedimensional bubbles can be changed, and the appearance and shape of the data inside can be adjusted (Figure 7).

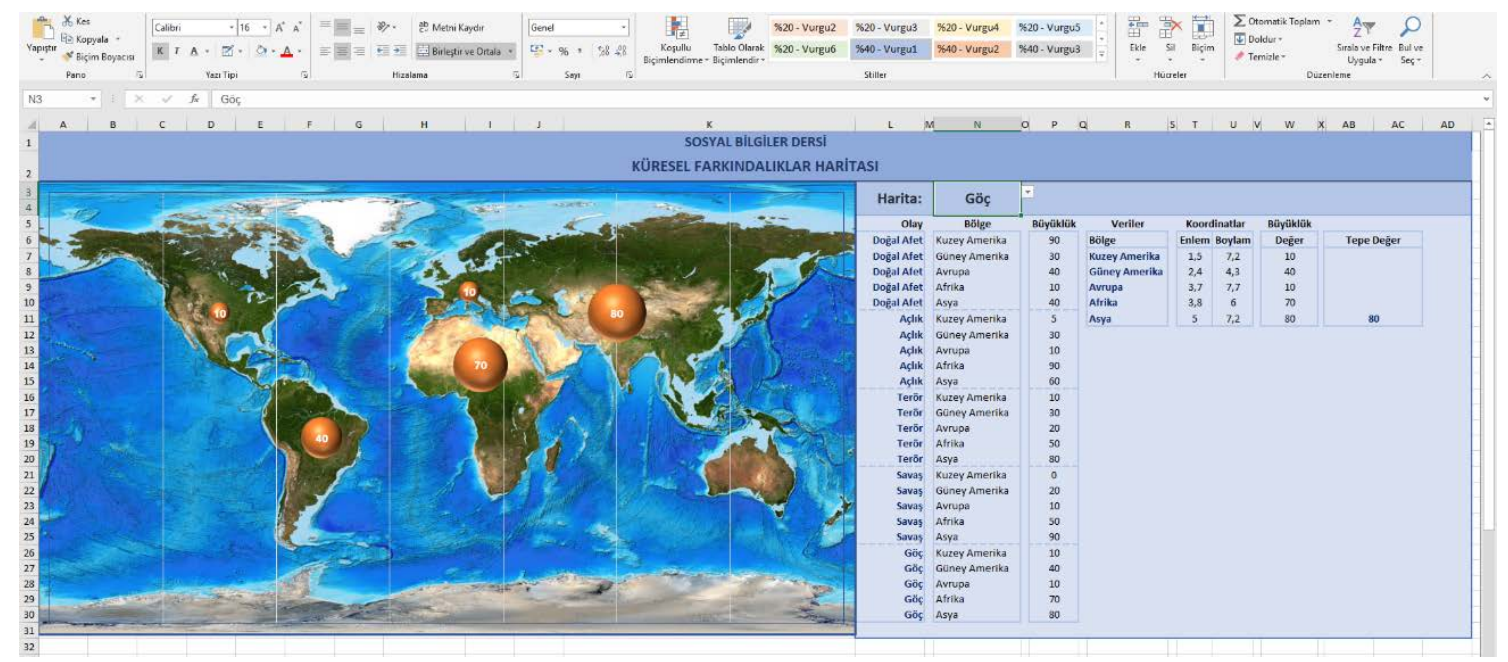

Fig. 7. Dynamic map in development (design) phase

\section{Using the prototype}

The dynamic map developed in the second stage of the rapid prototyping model was used A dynamic map has been tested in this framework on a different computer (hardware variety), operating system, and Microsoft Office versions. It has been observed that there is no problem in the use of the dynamic map regardless of the computer and operating system, but there are various compatibility problems in older versions of Microsoft 
Office. However, the dynamic map works smoothly in versions after 2013 (Figure 8).

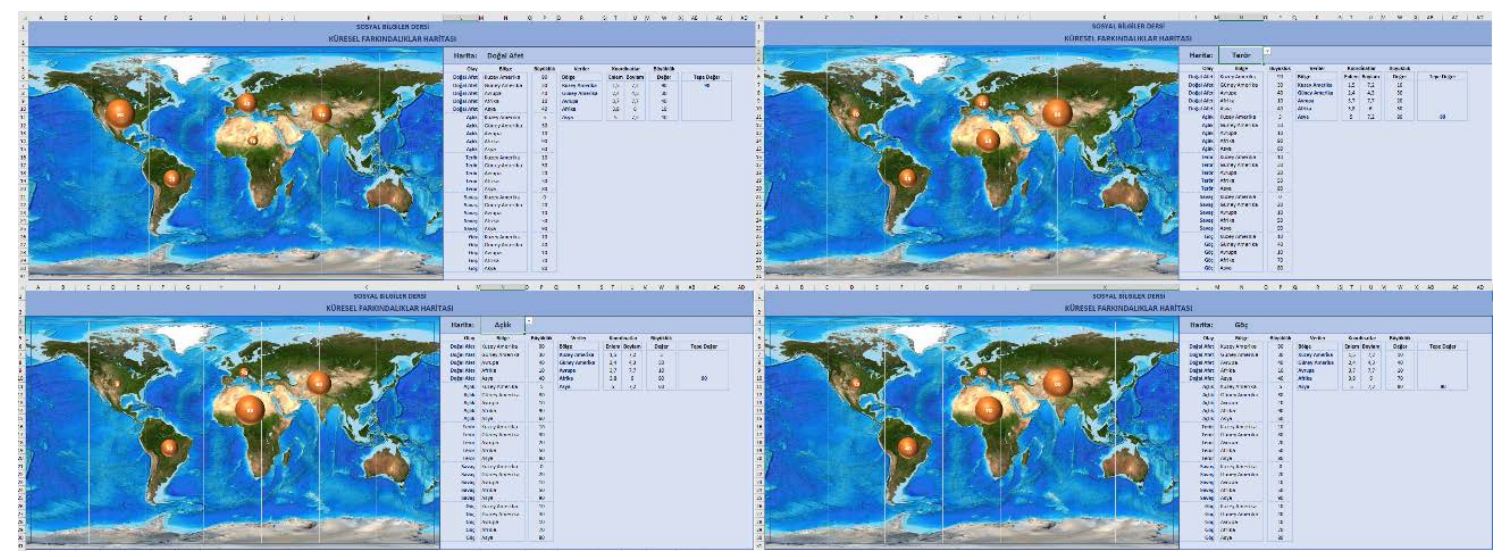

Fig. 8. Dynamic map using the prototype

Depending on the dynamic map's values, some points in the coordinate plane do not show the correct regions. Because the $x, y$ values are in a dynamic format, the latitude and longitude columns' parameter values have been rearranged. It has been determined that there is no problem following this process.

\section{Application and control}

At this stage, the three users (i.e. social studies teachers) tested the dynamic map's stable working control as a systematic structure. For this, the anonymous users on http://www.precoder.net, a domain name owned by the researcher, were asked to use the dynamic map as beta users. Three social studies education experts participated in the study anonymously and reported that the system works stably. Thus, the final prototype of the dynamic map was revealed.

\section{RESULTS}

Findings for determining the reflection levels of the acquisitions on the dynamic map are provided in Table 2. It shows that social studies teaching experts stated that the outcomes on the dynamic map can mostly be achieved with the map. 
Table 2. Reflection of acquisitions in dynamic map

\begin{tabular}{|c|c|c|c|}
\hline \multirow[b]{2}{*}{ 点 } & \multirow[b]{2}{*}{$\begin{array}{l}\text { Acquisitions } \\
\text { Outcome.6.7.3. The student analyses Turkey's } \\
\text { international roles based on its political, military, } \\
\text { economic and cultural characteristics. }\end{array}$} & \multicolumn{2}{|c|}{ Views } \\
\hline & & $\begin{array}{l}\text { Abstain } \\
\text { Expert3 }\end{array}$ & $\begin{array}{l}\text { Positive } \\
\text { Expert1, } \\
\text { Expert2 }\end{array}$ \\
\hline \multirow{3}{*}{$\stackrel{\substack{0\\
}}{\frac{0}{0}}$} & $\begin{array}{l}\text { Outcome.7.7.1. The student gives examples of } \\
\text { international organizations of which Turkey is a } \\
\text { member. }\end{array}$ & Expert3 & $\begin{array}{l}\text { Expert1, } \\
\text { Expert2 }\end{array}$ \\
\hline & $\begin{array}{l}\text { Outcome.7.7.2. The student recognizes the } \\
\text { economic regions and organizations with which } \\
\text { Turkey is associated. }\end{array}$ & Expert3 & $\begin{array}{l}\text { Expert1, } \\
\text { Expert2 }\end{array}$ \\
\hline & $\begin{array}{l}\text { Outcome.7.7.4. The student develops ideas for } \\
\text { solving global problems with classmates. }\end{array}$ & - & $\begin{array}{l}\text { Expert1, } \\
\text { Expert2, } \\
\text { Expert3 }\end{array}$ \\
\hline
\end{tabular}

The expert opinions regarding the reflection of the expected outcome for the sixth grader are the following:

Outcome.6.7.3. The student analyses Turkey's international roles based on its political, military, economic and cultural characteristics.

Abstain:

Expert3: "I guess that the teacher can convey these by associating it with the map. The map alone may not reflect it. At this point, I was hesitant."

Positive:

Expert1: "States' global tasks can overcome global problems. The purpose and content of this acquisition have already been created beforehand. Therefore, the outcome can be reflected on the map in any way."

Expert2: "This map can be a good association tool to show students how important is Turkey in its region, where global problems are building up."

All expert opinions on the reflection of the acquisitions in the seventh grade are the following:

Outcome.7.7.1. The student gives examples of international organizations of which Turkey is a member.

Abstain:

Expert3: "I think similarly again. I guess that the achievements can be fully reflected with teacher's support."

Positive:

Expert1: "The organizations that take part in the achievements have various roles in global problems. Therefore, it is possible for me to reflect the acquisitions directly." 
Expert2: "The fact that the World Health Organization is constantly on the agenda during the pandemic period shows the importance of global institutions and organizations in solving global problems. The map presents data on global problems and correlates them with the relevant organizations, allowing the acquisition to be reflected."

Outcome.7.7.2. The student recognizes the economic regions and organizations with which Turkey is associated.

Abstain:

Expert3: "We know that the global economic order is at the root of global problems. However, I still think that global problems can be conveyed with teachers' efforts for this outcome. I am not sure whether the map itself is enough to convey messages for this outcome".

Positive:

Expert1: "The economic conditions of today's world play a role in the formation of global problems. In this respect, my achievement is meaningful, and I think it is very compatible with the map."

Expert2: "Global problems on the map can be overcome with a global economic balance. The possibility of this happening is a separate matter of discussion. However, it is very important to at least make students perceive the problems in our region and to be able to associate them with our international rights. I guess that this map can create a network of relationships, especially between topics."

Outcome.7.7.4. The student develops ideas for solving global problems with classmates.

Positive:

Expert1: "The content of this outcome can be fully reflected with this dynamic map because the acquisition is all about global problems."

Expert3: "Since I think that your map can serve as a bridge between global problems and solutions, I think that multidimensional solutions can be produced by students to global problems. Of course, the teacher's contribution is very important here."

The findings obtained from the perspectives on the dynamic map are presented in Table 3.

Table 3. Insights into the dynamic map

\begin{tabular}{llc}
\hline Themes & Views & Views \\
Positive & It can embody the content. & Expert1 \\
& It can provide the association. & Expert2 \\
Abstain & Teacher support may be required. & Expert3 \\
\hline
\end{tabular}


Table 3 shows that social studies teaching experts expressed their insights about the dynamic map as possible to embody the outcomes in the curriculum.

The views of social studies teaching experts are the following:

Positive:

Expert1: "The study can make the content concrete by providing visualizations and instant reflection of the changes."

Expert2: "I think that establishing links between the acquisitions related to the global problems in the map can also provide the association."

Abstain:

Expert3: "The dynamic map will be very useful, but the only point I stumble upon is being dependent on the teacher too much."

\section{SCUSSION AND CONCLUSIONS}

In this study, the stages of creating a simple dynamic map in Microsoft Excel without the need for programming knowledge are explained according to the rapid prototyping model. In this context, the values entered in the columns were simply converted into parametric values, and a map with a coordinate plane was created. Data validation and classification of parametric data were then provided to determine the map type. To make the themed data dynamic, the values of all independent variables were collected using a simple formula. Thus, it enables us to retrieve the values of each field in the map according to the map type.

The first result shows that dynamic maps can reflect the expected outcomes in the curriculum. This result is similar to the results obtained by evaluating the courses supported by dynamic maps using academic achievement tests created in line with the outcomes (İneç, 2012, 2017). The second result is that dynamic maps can embody the content of the lesson; teacher support is also needed.

The dynamic map in this study may directly support related outcomes within mathematical, science/technology, digital and social/civic-related competencies which are provided in the curriculum of the 2018 Social Studies Teaching Program of the Turkish Ministry of National Education. This result is in line with the literature putting forward the relationship between the use of mapping mathematics skills (Pala \& Başıbüyük, 2019) and learning skills (Buğdaycı \& Selvi, 2019). In addition, in the SSTP, the relevant learning area embodies global problems in the way that it explains the effects of globalization. In this framework, the material can be used to support the content of the global connections learning area and skills such as map literacy. This result is also in line with the literature which shows a relationship between map use and map literacy (Aksoy \& Ablak, 2019). In 
A DYNAMIC MAP DESIGN FOR GLOBAL AWARENESS ...

contrast, it is known that material infrastructure, such as maps, is insufficient for learning due to students' weak mapping skills (Gökçe, 2015).

\section{RECOMMENDATI ONS}

- Dynamic maps created in Microsoft Excel should be used to support other learning areas of social studies courses,

-Dynamic maps should be used to support and develop the other skills in social studies courses, and

- Dynamic maps should be designed to reflect and structure the content for social studies courses, and their effect on skills and learning should be tested in scientific research.

\section{References}

Aksoy, B. \& Ablak, S. (2019). An Evaluation of Map Literacy of Social Studies Preservice Teachers. Participatory Educational Research (PER), 6(2), 158168. DOI: http://dx.doi.org/10.17275/per.19.19.6.2.

Bayar, F. (2008). Küreselleşme Kavramı ve Küreselleşme Sürecinde Türkiye [The Concept of Globalization and the Globalization Process in Turkey]. Uluslararası Ekonomik Sorunlar [International Economic Problems], XXXII, 25-34.

Bednarz, S.W., Acheson, G. \& Bednarz, R.S. (2006). Maps and Map Learning in Social Studies. Social Education, 70(7), 398-432.

Bekdemir, Ü. \& Polat, S. (2016). Map Usage in the 5th and 6th Grade Social Sciences Books. The Journal of EKEV Academy, 20(68), 363-382.

Buğdaycı, İ. \& Selvi, H.Z. (2019). Cartography for Basic Education: Atlas Production for Primary and Secondary Schools. In $17^{\text {nd }}$ Turkey Scientific and Technical Conference. $\quad$ Retrieved 12 February 2021, from https://www.hkmo.org.tr/resimler/ekler/6a0a1cdf389a998_ek.pdf.

Burnouf, L. (2004). Global Awareness and Perspectives in Global Education. Canadian Social Studies, 38(3), Retrieved 12 February 2021, from https://files.eric.ed.gov/fulltext/EJ1073942. pdf.

Çakmak, Z. \& Bulut, B. (2019). Global Literacy Skills from the Social Studies Perspective. Mehmet Akif Ersoy University Journal of Education Faculty, 51, 160-180. DOI: DOI: 10.21764/ maeuefd.537314.

Çelikkaya, T. (2013). The Application Levels of Instructional Tools and Materials by Social Studies Teachers. Ondokuz Mayis University Journal of Education Faculty, 32(1), 73-105.

Darakçı, S. (2014). Use of Map in the Social Studies Teaching Program and Textbooks. Mehmet Akif Ersoy University Journal of The Institute of Educational Sciences, 3(4), 15-31. 


\section{ZEKERİYA FATİH İNEÇ}

Dulamă, M.E. \& Ilovan, O.-R. (2016). How Powerful is Feedforward in University Education? A Case Study in Romanian Geographical Education on Increasing Learning Efficiency. Educational Sciences: Theory \& Practice (ESTP), Kuram ve Uygulamada Eğitim Bilimleri (KUYEB), 16(3), 827-848. DOI: 10.12738/estp.2016.3.0392.

Dulamă, M.E. (2014). The Use of Geographic Thematic Maps in E-Learning. Exemplification: Bobota Village, Romania. In Vlada, M., Albeanu, G. \& Popovici, D.M. (eds.), Proceedings of the 9th International Conference on Virtual Learning (pp. 52-59). București: Editura Universității.

Dulamă, M.E., Ilovan, O.-R. \& Niţoaia, A. (2016). Forming and Assessing the Competence to Elaborate Proposals of Spatial Planning Measures for Hydrographical Basins. PedActa, 6(1), 16-27.

Duman, H. (2011). Using Map in Teaching of Social Studies and Teachers' Opinions About Using Map. (Unpublished master thesis). Uludag University Institute of Education Sciences. Bursa, Turkey.

Gibson, K.L., Rimmington, G.M. \& Landwehr-Brown, M. (2008). Developing Global Awareness and Responsible World Citizenship with Global Learning. Roeper Review, 30(1), 11-23. DOI: 10.1080/02783190701836270.

Gökçe, N. (2015). Social Studies in Improving Students' Map Skills: Teachers' Opinions. Educational Sciences: Theory \& Practice, 15(5), 1345-13652. DOI 10.12738/estp.2015.5.0071.

Hanvey, R.G. (1975). An Attainable Global Perspective. New York: Center for War/Peace Studies.

Hanvey, R.G. (1982). An Attainable Global Perspective. Theory into Practice, 21(3), 162-167.

İneç, Z.F. (2012). Web Based Geographical Information System Application in Social Studies Education. (Unpublished master thesis). Erzincan University, Institute of Social Sciences. Erzincan, Turkey.

İneç, Z.F. (2017). The Effectiveness of Geo-Media Assisted Authentic Learning Environment on Learning in the Social Studies Lessons. (Unpublished doctoral dissertation). Erzincan University, Institute of Social Sciences. Erzincan, Turkey.

Kabapınar, Y. (2014). Kuramdan Uygulamaya Sosyal Bilgiler Öğretimi [Social Studies Teaching from Theory to Practice]. (4 $4^{\text {nd }}$ ed.). Ankara: Pegem Akademi.

Karasar, N. (2019). Bilimsel İrade Algı Çerçevesi ile Bilimsel Araştırma Yöntemi [Scientific Research Method with Scientific Will Perception Framework]. (34th ed.). Ankara: Nobel Akademic Publishing.

Karip, E. (2005). Globalization and Education 2010 Lisbon Objectives. Kuram ve Uygulamada Eğitim Yönetimi, 42, 195-209.

Meydan, A. \& Öner, S. (2014). Effect of Teaching through Geographical Information Systems upon the Attitudes of Students towards Geography Lesson. Turkish Studies, 9(11), 407-417.

Microsoft Support (n.d.). SUMIFS function. Retrieved 29 August 2020, from https://support.microsoft.com/tr-tr/office/çoketopla-işlevi-c9e748f5-7ea7455d-9406-611cebce642b 
Miles, M.B. \& Huberman, A.M. (1994). Qualitative Data Analysis: An Expanded Sourcebook (2nd ed.). California: SAGE Publications.

Ministry of National Education [MoNE] (2018). Social Studies Course Curriculum. Retrieved 14 August 2020, from: http://muf redat.meb.gov.tr/Dosyalar/201812103847686SOSYAL\%20B\%C4\%BOLG\%C4\%BOLER\%20\%C3\%96\%C4\%9ERET\%C4\%B0 M\%20PROGRAMI\%20.pdf.

MTBlack (2016). Large World Physical Map. Retrieved 28 August 2020, from https://commons.wikimedia.org/wiki/File:Large_World_Physical_Map.png.

Ocak, M.A. (2011). Öğretim Tasarımı Modelleri [Instructional Design Models]. In Ocak, M.A. (ed.), Öğretim tasarımı. Kuramlar, modeller ve uygulamalar [Instructional Design. Theories, Models and Applications] (pp. 29-273). Ankara: Anı Publishing.

Oruç, Ş. \& Liman, E. (2012). A Review on The Maps and Figure Which Use in Social Studies Lesson Books. Firat University Journal of Social Science, 22(1), 145159.

Pala, Ş.M. \& Başıüyük, A. (2019). The Effect of Mathematics Skills on Map, Graphic and Table Reading Skills in Social Studies Courses. The International Journal of New Approaches in Social Studies (IJONASS), 3(1), 41-46.

Sönmez, Ö.F. \& Aksoy, B. (2012). Determination of Primary Education Secondary Stage Students' Map Skill Levels. International Periodical for the Languages, Literature and History of Turkish or Turkic, 7(1), 1905-1924.

Taşlı, İ., Çelik, H. \& Taşlı, M. (2007). Configurative Teach and Abstract of Using Map in Social Studies in Some Uncertain States (Demırci-Gordes Sample). Social Sciences, 5, 57-68.

Tripp, S. \& Bichelmeyer, B. (1990). Rapid Prototyping: An Alternative Instructional Design Strategy. Educational Technology Research and Development, 38(1), 31-44.

Ulusoy, K. \& Gülüm, K. (2009). To Use of Teachers to the Teaching Materials while Studying History and Geography Subjects in Social Science Lessons. Kırşehir Faculty of Education Journal (J KEF), 10(2), 85-99.

Yazıcl, K. (2006). Visual Tools Used in Social Studies: Maps-Spheres, Pictures, Tables and Graphics. The Journal of Institute of Social Sciences, 15, 651662.

Yıldııı, A. \& Şimşek, H. (2013). Sosyal Bilimlerde Nitel Araştırma Yöntemleri [Qualitative Research Methods in the Social Sciences]. Ankara: Seçkin Publishing. 